\title{
Serum retinol binding protein 4 is negatively related to estrogen in Chinese women with obesity: a cross-sectional study
}

Qian $\mathrm{Li}^{1+}$, Weiyun $\mathrm{Wu}^{2+}$, Huandong Lin ${ }^{1}$, Xinxia Chang ${ }^{1}$, Hua Bian ${ }^{1}$, Mingfeng Xia ${ }^{1}$, Hongmei Yan ${ }^{1 *}$ and Xin Gao ${ }^{1^{*}}$

\begin{abstract}
Background: The association between serum Retinol Binding Protein 4 (RBP4) and obesity is still controversial. Serum RBP4 levels varies by gender, and estradiol may play a role in the difference. To investigate the participation of sex hormones in the association of RBP4 and obesity in humans, we measured serum RBP4, BMI, and sex hormones in 87 women from the outpatient.
\end{abstract}

Methods: Eighty-seven subjects of Chinese women origin from the outpatient (aged $40.22 \pm 15.54$ years) were enrolled. Subjects with diseases affecting the metabolic state or not suitable to participate in this study were excluded. Anthropometrics and laboratory tests, including lipid profile, luteinizing hormone (LH), follicle stimulating hormone (FSH), prolactin (PRL), estradiol (E2),progesterone (PROG), testosterone (TESTO), and dehydroepiandrosterone (DHEA) were conducted. Serum RBP4 was detected by an enzyme immunoassay kit and validated by quantitative Western blotting.

Results: Circulating RBP4 levels were positively associated with BMI, waist circumference, waist-to-hip ratio (WHR), systolic and diastolic (SBP), diastolic blood pressure (DBP), triglycerides (TG), low high-density lipoprotein cholesterol(LDL-c), and testosterone (TESTO) in the total group. While only in obese individuals, serum RBP4 levels were negatively associated with E2. The highest value was in the subjects with both obesity and the low estrogen level. Multiple linear regression analysis revealed that RBP4 correlated independently with TG, TC and insulin in all subjects, TC in non- obese individuals. However, E2 were significantly associated with serum RBP4 only in obese individuals.

Conclusions: RBP4 could be a marker of obesity-related factors; estrogen was negatively related to RBP4 and might be one of the influential factors.

Keywords: Retinol binding protein 4, Estrogen, Obesity

\section{Background}

Retinol-binding protein 4 (RBP4), belongs to the lipocalin family of proteins, which is released primarily by the liver, has also been shown to be released by adipose tissue as the second highest rate of expression $[1,2]$. In humans, serum RBP4 levels have been suggested to

\footnotetext{
* Correspondence: 13761666976@126.com; zhongshan_endo@126.com ${ }^{\dagger}$ Equal contributors

${ }^{1}$ Department of Endocrinology and Metabolism, Shanghai Zhongshan Hospital, Fudan University, Shanghai 200032, China

Full list of author information is available at the end of the article
}

provide the association with the degree of adiposity [3]. Obesity is associated with a dramatic increase in the prevalence of type 2 diabetes, and also has been associated with many other chronic diseases and comorbidities. Over the past few decades, the prevalence of obesity has increased greatly worldwide and in China, especially $[4,5]$. Thus, the prevention of obesity among people should be considered a priority of health care policy.

Several studies show that serum RBP4 levels correlate inversely with the severity of insulin sensitivity, which is positively with obesity and type 2 diabetes, as well as 
components of the metabolic syndrome, and can be used as a noninvasive serological indexes reflecting the metabolic abnormalities [6-8]. However, there is also conflicting data between RBP4 and obesity was demonstrated in other studies $[9,10]$. Therefore, the relationship of RBP4 and obesity is still controversial in adult. RBP4 does not reach adult plasma levels until puberty, after which plasma levels are changeable, based on the menstrual cycle. And this variation in the plasma RBP level appears to correlate with peak levels of estradiol and menopausal status in women $[11,12]$. It also has been proved that plasma RBP4 concentration varies by gender, generally being lower in women than in men participants. Several previous studies hypothesized that sex hormones may play a role in the difference $[10,12,13]$. So it is necessary to investigate the participation of sex hormones on the levels of RBP4 in humans, especially in woman.

Therefore, the major aim of the present study is to evaluate the association between RBP4 levels, obesity, sex hormones, as well as other metabolic parameters in Chinese women. Additionally, we sought to explore the possible effect of sex hormones on the relation with obesity and RBP4.

\section{Methods}

\section{Subjects}

We consecutively selected 138 subjects from the general population who had undergone medical check-ups at the outpatient department of Endocrinology of Zhongshan hospital, Fudan university from Oct.2013 and Aug.2014. After excluding 51 of the 138 subjects, a total of 87 subjects were enrolled in our study. Exclusion factors were diseases affecting the metabolic state or not suitable to participate in this study. Women presenting endometriosis, uterinefibroid, breast cancer and those with hormone-dependent cancer were excluded. Hyperthyroidism, hypothyroidism, diabetes, mental disease, serious disease with dysfunction of heart, liver, kidney, were excluded as well as those using estrogen replacement therapy. The study was approved by the human research ethics committee of Zhongshan hospital, Fudan University and informed consent was obtained from all subjects.

\section{Anthropometric and biochemical measurements}

Height $(\mathrm{cm})$ and weight $(\mathrm{kg})$ of participants, wearing light clothing and without shoes, was measured with stadiometers and calibrated balance-beam scales, respectively. BMI was calculated as weight in kilograms divided by the square of height in meters. Waist circumference $(\mathrm{cm})$ was measured with a non-stretchable tape at the end of a normal expiration, at the smallest horizontal circumference between the ribs and iliac crest. Thus, waisthip ratio (WHR) was calculated as waist circumference divided by hip circumference. Blood pressure was measured in the right arm in the seated position, after at least a $5 \mathrm{~min}$ rest, and the average of the three blood pressures was used as the final blood pressure. Blood samples were collected after a fasting period of at least $10 \mathrm{~h}$ overnight. Serum total cholesterol (TC), triglycerides (TG), highdensity lipoprotein cholesterol (HDL-c), and low-density lipoprotein cholesterol (LDL-c) were determined by enzymatic methods with a Hitachi 7600 analyzer (Hitachi,Ltd. Tokyo, Japan). Serum insulin (mU/L) was measured with an insulin radioimmunoassay kit (kit from Beijing North Biotechnology Research Institute). Follicle stimulating hormone (FSH), luteinizing hormone (LH), prolactin (PRL), estradiol (E2), progesterone (PROG), testosterone (TESTO), dehydroepiandrosterone (DHEA) were checked. Methods for measuring blood hormones were electrochemiluminescence immunoassay (ECLIA), and kits were used for ECLIA supplied by Roche Diagnostic Systems, GmbH,Mannheim, Germany. Serum RBP4 $(\mu \mathrm{g} / \mathrm{ml})$ was measured in duplicate by a sandwich ELISA developed in-house, using affinity chromatography purified polyclonal and monoclonal antibodies generated against recombinant human RBP4 protein. The assay system was subsequently cross validated by Western blot analysis [14]. According to recommendations of the Working Group on Obesity in China, BMI between 18.5 and $24.0 \mathrm{~kg} / \mathrm{m} 2$ was considered normal. BMI between 24.0 and $28.0 \mathrm{~kg} / \mathrm{m} 2$ was defined as overweight, and over 28.0 was defined as obesity [15].

\section{Statistical analyses}

Mean (standard deviation), median (interquartile range), were tabulated for demographic, and laboratory characteristics by BMI. Differences in the distributions of these variables between non-obese and obese were calculated by the Chi-Square test for categorical variables, ANOVA for normally distributed continuous variables. Following this, Pearson's correlation was used to examine the association of serum RBP4 and other parameters. Multiple testing was corrected using LSD method (Equal Variances Assumed) or Games-Howell method (Equal Varance not assumed). Multiple stepwise regression analysis was used to examine the association of estrogen and serum RBP4 and other parameters. All statistical analyses were performed using SPSS18.0 (SPSS Inc., Chicago, Illinois, USA), $p$ values $<0.05$ were considered significant.

\section{Results}

The mean age of study participants was $40.22 \pm 15.54$ years. Demographic and laboratory characteristics stratified by BMI are presented in Table 1. Compared to nonobese, obese individuals had higher waist circumference, hip circumference, waist-to-hip ratio (WHR), systolic 
Table 1 Basic characteristics of all the subjects

\begin{tabular}{|c|c|c|c|}
\hline & Non-obese $(n=45)$ & Obese $(n=42)$ & $P$ value \\
\hline Age (year) & $41.18(16.07)$ & $39.19(15.08)$ & 0.554 \\
\hline BMI (kg/m2) & $22.69(3.68)$ & $34.79(4.99)$ & $<0.001$ \\
\hline Waist (cm) & 82.49 (10.55) & $110.48(14.53)$ & $<0.001$ \\
\hline Hip (cm) & $94.09(7.18)$ & 116.65 (10.69) & $<0.001$ \\
\hline WHR (cm/cm) & $0.88(0.08)$ & $0.95(0.08)$ & $<0.001$ \\
\hline SBP $(\mathrm{mmHg})$ & $118.00(16.67)$ & $129.76(16.7)$ & 0.002 \\
\hline $\mathrm{DBP}(\mathrm{mmHg})$ & $75.52(8.55)$ & $81.95(11.92)$ & 0.005 \\
\hline $\mathrm{TC}(\mathrm{mmol} / \mathrm{L})$ & $4.35(0.94)$ & $4.54(0.83)$ & 0.326 \\
\hline TG $(\mathrm{mmol} / \mathrm{L})$ & $1.23(0.70)$ & $1.70(0.90)$ & 0.008 \\
\hline HDL-c (mmol/L) & $1.27(0.40)$ & $1.02(0.25)$ & 0.001 \\
\hline LDL-c (mmol/L) & $2.53(0.81)$ & $2.76(0.70)$ & 0.155 \\
\hline $\mathrm{LH}(\mathrm{mlU} / \mathrm{mL})$ & $8.00(0.30-59.70)$ & $5.70(0.30-59.70)$ & 0.018 \\
\hline FSH (mIU/mL) & $5.60(0.10-114.30)$ & $5.30(0.20-69.7)$ & 0.046 \\
\hline $\operatorname{PRL}(\mathrm{m} \mid \mathrm{U} / \mathrm{mL})$ & $380.60(23.60-9544.00)$ & $381.65(10.40-2042.00)$ & 0.562 \\
\hline E2 (pmol/L) & $114.70(22.20-617.60)$ & $135.80(37.20-859.90)$ & 0.661 \\
\hline PROG (nmol/L) & $1.40(0.10-37.55)$ & $1.40(0.20-21.27)$ & 0.733 \\
\hline TESTO (nmol/L) & $0.99(0.10-23.50)$ & $1.78(0.30-25.90)$ & 0.510 \\
\hline DHEA (umol/L) & $2.85(0.40-16.70)$ & $4.20(1.20-18.50)$ & 0.071 \\
\hline Fasting insulin (mU/L) & $9.50(5.00-57.20)$ & $15.50(3.60-60.50)$ & 0.295 \\
\hline Serum RBP4 $(\mu \mathrm{g} / \mathrm{ml})$ & $30.07(7.83)$ & $33.07(7.06)$ & 0.064 \\
\hline
\end{tabular}

Data are presented as means(S.D) or median (range)

$B M I$ body-mass index, SBP systolic blood pressure, DBP diastolic blood pressure, WHR waist-to-hip ratio, $T C$ total cholesterol, $T G$ triglycerides, $H D L-c$ high-density lipoprotein cholesterol, $L D L-c$ low-density lipoprotein cholesterol, $L H$ luteinizing hormone, $F S H$ folliclestimulating hormone, $P R L$ prolactin, $E 2$ estradiol, $P R O G$ progesterone, TESTO testosterone, DHEA dehydroepiandrosterone, RBP4 retinol binding protein 4

and diastolic (SBP), diastolic blood pressure (DBP), triglycerides (TG), but lower high-density lipoprotein cholesterol (HDL-c), luteinizing hormone (LH), and follicle stimulating hormone (FSH). There are no differences between non-obese and obese individuals in age, total cholesterol (TC), low high-density lipoprotein cholesterol(LDL-c), prolactin (PRL), estradiol (E2), progesterone (PROG), testosterone (TESTO), dehydroepiandrosterone (DHEA), fasting insulin and serum RBP4.

The Pearson correlation coefficients for associations between RBP4 concentrations and other parameters are summarized in Table 2. In all subjects, serum RBP4 levels were significantly positively associated with BMI, waist circumference, WHR, SBP, DBP, TC, TG, LDL-c and TESTO, but not associated with hip circumference, HDL-c, LH, FSH, PRL, E2, PROG and DHEA. In nonobese individuals, serum RBP4 levels were significantly positively associated with BMI, SBP, TC, TG, LDL-c, but not associated with waist circumference, hip circumference, DBP and the other variables mentioned above. However, in obese individuals, serum RBP4 levels were significantly positively associated with TC, TG, TESTO, and DHEA, whereas negatively associated with insulin and E2. But not associated with BMI, WHR and the other variables mentioned above, either.

Especially, we found that Serum RBP4 level was negatively correlated with estrogen in obese individuals $(r=$ $-0.374, p=0.032$ ), but no longer existed when in nonobese individuals $(r=-0.01, p=0.962)$ (Fig. 1). To further explore the association among serum RBP4 levels, BMI and E2, we built interaction terms between serum RBP4 levels and two categories of BMI and estradiol (E2) stratified by the median values at the same time. There were significant differences in serum RBP4 levels between groups classified by E2 level within the same BMI strata (Table 3). RBP4 levels were the highest in the subjects with both obesity and the low estrogen level $(37.08 \pm 7.29 \mu \mathrm{g} / \mathrm{ml}$ vs. $26.77 \pm 3.47 \mu \mathrm{g} / \mathrm{ml}, 29.64 \pm 7.8$ $\mu \mathrm{g} / \mathrm{ml}$, and $30.9 \pm 7.18 \mu \mathrm{g} / \mathrm{ml}, P$ for trend $<0.001$, respectively), compare to those with neither obesity nor low estrogen levels, individuals with no-obese but low estrogen levels, and individuals with obesity but high estrogen levels.

A stepwise multiple linear regression analysis was performed using serum RBP4 level as a dependent variable. Independent variables were those parameters, which 
Table 2 Pearson's correlation analysis of serum RBP4 in all the subjects

\begin{tabular}{|c|c|c|c|c|c|c|}
\hline & \multicolumn{2}{|c|}{ Total $(n=87)$} & \multicolumn{2}{|c|}{ Non-obese $(n=45)$} & \multicolumn{2}{|c|}{ Obese $(n=42)$} \\
\hline & $r$ & $P$ & $r$ & $P$ & $r$ & $P$ \\
\hline BMl & $0.308^{* *}$ & 0.004 & $0.377^{*}$ & 0.011 & 0.158 & 0.316 \\
\hline Waist & $0.258^{*}$ & 0.025 & 0.189 & 0.277 & 0.097 & 0.553 \\
\hline Hip & 0.188 & 0.107 & 0.147 & 0.400 & -0.070 & 0.666 \\
\hline WHR & $0.271^{*}$ & 0.019 & 0.136 & 0.436 & 0.260 & 0.105 \\
\hline SBP & $0.302^{* *}$ & 0.005 & $0.352^{*}$ & 0.019 & 0.139 & 0.386 \\
\hline DBP & $0.270^{*}$ & 0.013 & 0.276 & 0.069 & 0.198 & 0.214 \\
\hline $\mathrm{TC}$ & $0.422^{* *}$ & $P<0.001$ & $0.467^{* *}$ & 0.001 & $0.337^{*}$ & 0.029 \\
\hline TG & $0.497^{* *}$ & $P<0.001$ & $0.315^{*}$ & 0.037 & $0.619^{* *}$ & $P<0.001$ \\
\hline $\mathrm{HDL}$ & -0.078 & 0.476 & 0.061 & 0.693 & -0.129 & 0.415 \\
\hline LDL & $0.295^{* *}$ & 0.006 & $0.388^{* *}$ & 0.009 & 0.115 & 0.468 \\
\hline LH & 0.110 & 0.317 & 0.238 & 0.125 & 0.025 & 0.877 \\
\hline FSH & 0.148 & 0.171 & 0.267 & 0.076 & 0.053 & 0.737 \\
\hline PRL & -0.151 & 0.166 & -0.132 & 0.398 & -0.255 & 0.103 \\
\hline E2 & -0.207 & 0.113 & -0.01 & 0.962 & $-0.374^{*}$ & 0.032 \\
\hline PROG & -0.119 & 0.298 & -0.018 & 0.910 & -0.317 & 0.063 \\
\hline TESTO & $0.229^{*}$ & 0.045 & 0.102 & 0.541 & $0.344^{*}$ & 0.032 \\
\hline DHEA & 0.210 & 0.055 & 0.050 & 0.747 & $0.329^{*}$ & 0.038 \\
\hline INSUL & -0.262 & 0.079 & -0.258 & 0.418 & $-0.423^{*}$ & 0.013 \\
\hline
\end{tabular}

${ }^{*} P<0.05 ; * * P<0.01$

$B M I$ body-mass index, SBP systolic blood pressure, DBP diastolic blood pressure, WHR waist-to-hip ratio, TC total cholesterol, TG triglycerides, HDL-c high-density lipoprotein cholesterol, $L D L-c$ low-density lipoprotein cholesterol, $L H$ luteinizing hormone, FSH folliclestimulating hormone, PRL prolactin, E2 estradiol, PROG progesterone, TESTO testosterone, DHEA dehydroepiandrosterone, RBP4 retinol binding protein 4 were significantly associated with RBP4 in Pearson's correlation analysis. In all subjects, TG (Standardized Coefficients Beta $=0.509, \quad P<0.001), \quad$ TC $\quad$ (Standardized Coefficients Beta $=0.260, P=0.047$ ) together with Insulin (Standardized Coefficients Beta $=-0.249, p=0.035$ ) were independent variables significantly associated with serum RBP4. In non-obese individuals, TC (Standardized Coefficients Beta $=0.582, P=0.006$ ) was independently associated with serum RBP4, while in obese individuals, Insulin (Standardized Coefficients Beta $=-0.518, p=$ 0.006) together with E2 (Standardized Coefficients Beta $=-0.438, p=0.013)$ were significantly associated with serum RBP4 (Table 4).

\section{Discussion}

In the current study, we found that serum RBP4 levels were inversely associated with E2 levels in a cohort of Chinese women patients with obesity. To the best of our knowledge, this study is the first showing that circulating RBP4 is associated not only with BMI but also E2 levels in Chinese women patients, which implied that estradiol might be an impact factor on the relation between obesity and circulating RBP4.

RBP4 has long-been known to be released by the liver, and it also has been shown that approximately $15 \%$ of circulating secretion results from adipose tissue, and down-regulates the glucose transporter GLUT4, which acts as the rate-limiting step in insulin-activated glucose transport across both muscle and adipocyte membranes $[16,17]$. Results from the previous study also suggested that RBP4 levels had an important effect on obesity indices, as measured by BMI, WC, waist-to-hip ratio, and even body fat percentage $[10,14,18,19]$. Especially, a
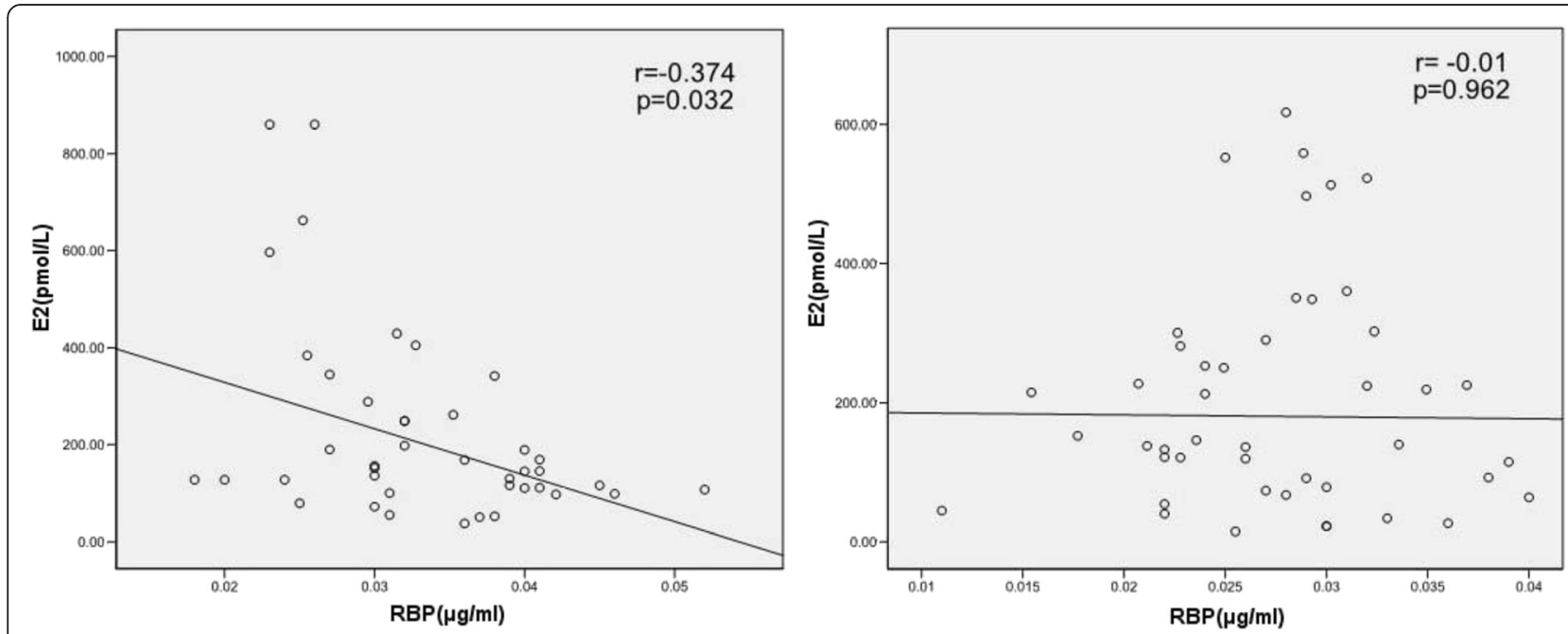

Fig. 1 Pearson's correlation analysis between RBP4 $((\mu \mathrm{g} / \mathrm{ml}))$ and E2(pmol/L). Serum RBP4 level was negatively correlated with estrogen in obese individuals $(r=-0.374, p=0.032$, a However, the association between RBP4 and estrogen no longer existed when in non-obese individuals $(r=-0.01, p=0.962, \mathbf{b})$ 
Table 3 The mean concentration of RBP4 in women stratified by BMI and estradiol (E2) levels

\begin{tabular}{llll}
\hline Non-obese & Obese & \\
\hline$E 2>118.60(\mathrm{pmol} / \mathrm{L})$ & $\mathrm{E} 2<118.60(\mathrm{pmol} / \mathrm{L})$ & $\mathrm{E} 2>118.60(\mathrm{pmol} / \mathrm{L})$ & $\mathrm{E} 2<118.60(\mathrm{pmol} / \mathrm{L})^{\mathrm{a}, \mathrm{b}, \mathrm{c}}$ \\
$26.77 \pm 3.47(\mu \mathrm{g} / \mathrm{ml})$ & $29.64 \pm 7.80(\mu \mathrm{g} / \mathrm{ml})$ & $30.9 \pm 7.18(\mu \mathrm{g} / \mathrm{ml})$ & $37.08 \pm 7.29(\mu \mathrm{g} / \mathrm{ml})$ \\
\hline
\end{tabular}

${ }^{\mathrm{a}} P<0.05$ vs Non-obese group with high E2 level

${ }^{\mathrm{b}} P<0.05$ vs Non-obese group with low E2 level

${ }^{c} P<0.05$ vs Obese group with high E2 level

E2 corresponds to baseline estradiol levels. Cut-off point was set at median value

prospective study suggested that baseline RBP4 levels predict subsequent increase in WC in a Korean adolescent population [20]. Similar to prior studies in adults, we found that the RBP4 levels were positively correlated with most of the obesity indices in Chinese women, including BMI, waist circumference, and WHR in the whole subjects. The results mentioned above indicate that RBP4 might be a useful marker of obesity-related factors in subjects. There are some discrepant results from other studies have questioned these associations, failing to demonstrate associations with obesity [21-23]. The possible reasons for this difference may due to different study subjects in the ethnicity, age, and size of the samples. However, when all women were divided into different groups according to BMI, there are no differences between non-obese and obese individuals in serum RBP4 levels. And the same link between circulating RBP4 levels and obesity indices was not founded in obese women, which implied that there are other mechanisms for regulating RBP4 levels.

In both adults and children, the concentration of serum RBP4 varies by gender, with levels lower in female than in male participants [13,24, 25]. Several previous studies supported that RBP4 levels were shown to be different between premenopausal and postmenopausal women and vary according to menstrual cycle [11, 25, 26]. It hypothesized that sex hormones may play a role in the gender discrepancy, which may also plays protective effect on women against the influence of RBP4. In our result, we found that serum RBP4 levels were significantly negatively associated with estrogen (E2) only in

Table 4 Multiple linear regression analysis of RBP4 and other parameters

\begin{tabular}{llcrc}
\hline & & Standardized coefficients beta & \multicolumn{1}{l}{ Sig } \\
\hline ALL & TG & 0.509 & 4.651 & $P<0.001$ \\
& TC & 0.260 & 2.098 & 0.047 \\
& INSUL & -0.249 & -2.240 & 0.035 \\
Non-obese & TC & 0.582 & 3.113 & 0.006 \\
Obese & E2 & -0.438 & -2.723 & 0.013 \\
& INSUL & -0.518 & -3.087 & 0.006
\end{tabular}

A step-wise multiple linear regression analysis was performed to determine the contributing factors to serum RBP4 levels. Independent variables included in multivariate regression model were variables which significantly associated with RBP4 in Pearson's correlation analysis obese women. When subjects were divided into four groups according to BMI and estrogen (E2) stratified by the median values, the highest value for serum RBP4 was in subjects with both obesity and the low estrogen level, the lowest value was in non-obese groups with high estrogen level. Multiple linear regression analysis also revealed that RBP4 correlated independently with TG, TC and insulin in all subjects, however, with E2 only in obese individuals. The possible mechanisms are as follow. Firstly, estrogen may have a direct effect on serum RBP4 expression. Tan et al found the RBP4 level is influenced by the effect of sex hormones and suggested 17bestradiol have a direct regulatory effecting on the RBP4 concentration in women with polycystic ovary syndrome [27]. Other researches indicated estrogen mediates retinoic acid metabolism by the regulation of RBP4 expression in adipose tissue, and the systemic deficiency of serum estrogen may activate a specific regulatory process and consequently, which induce the overexpression of RBP4 through ER in visceral adipocytes [28, 29]. Secondly, estrogen may convey an indirect effect by influencing the body fat distribution on serum RBP4. As one kind of adipocytokines, RBP4 was identified a sexual dimorphism for secretion in previous studies, which was partly attributed to the effect of sex hormones and body fat distribution [30, 31]. Estrogen has an important role in regulation of fat metabolism, and the effect of estrogen to reduction of lipolysis was through activation of estrogen receptor alpha (ER- $\alpha)$ in adipose tissue, then influenced body adiposity [32-34]. Lack of estrogen, people tend to accrue more visceral fat, which has been highly correlated to metabolic and cardiovascular risk; whereas accrue less fat in the subcutaneous depot [35]. In our previous study, we have found that circulating RBP4 is positively associated with the visceral fat, which implied that visceral fat might be a major source of excess circulating RBP4 [36]. Consistent with our findings, relationship of RBP4 and visceral fat, not subcutaneous fat, was confirmed by many other studies in different populations [37-39], which suggest that visceral obesity might play a key role in increasing the circulating RBP4 level. Therefore, when combining several factors, the group with both obesity and low estrogen level has the highest serum RBP4 levels. We also found that testosterone was positively associated with RBP4 levels in women, for DHEA only in obese women. 
The close relationship between other metabolic parameters and RBP4 in adult and adolescents has been observed in previous studies, in which RBP4 was positively associated with BP, lipid profiles, and FPG [20, 26, 40]. We also found that the RBP4 levels were positively correlated with most of the cardiometabolic risk factors, such as SBP, DBP, TC, TG and LDL. Especially, circulating RBP4 levels were found to be highly correlated with TC and TG, both in non-obese and obese subject. Consistent with our result, another research found higher triglyceride levels is correlated with higher RBP4 [41]. The possible mechanism is that retinoid have been known to affect the expression of several genes involved in triglyceride metabolism, including regulators of apo C-III production, hepatic and gastrointestinal triglyceride production and secretion, and beta-oxidation of fatty acids [42].

Some limitations of this study must be taken into consideration. Firstly, the cross-sectional design of the study represents a limitation, implicating that cause-and-effect relationship cannot be discerned. Secondly, our study subjects included only from the outpatient women. And the majority of individuals are middle-aged woman with variation of plasma estrogen, which may influence the levels of RBP4, as it changed during the menstrual cycle. The relation of RBP4 and estrogen is also restricted to only in obese women. Therefore, our results may not be applicable to the whole population. Finally, due to the limitation of data collection on all types of sex hormones, we got small sample size. As well as being small, the trials may have methodological weaknesses that could have resulted in bias.

\section{Conclusion}

In conclusion, RBP4 could be a marker of obesity-related risk factors, and it is negatively related to estrogen, restricted to obese individuals. The RBP4 levels were higher in the copresence of obesity and low estrogen, which suggested that their relationship was complicated and might influenced by estrogen and other confounding factors. Further experiments with larger groups of subjects are warranted to clarify the relationship between RBP4 and estrogen.

\section{Abbreviations \\ RBP4: retinol binding protein 4; BMI: body-mass index; SBP: systolic blood pressure; DBP: diastolic blood pressure; WHR: waist-to-hip ratio; TC: total cholesterol; TG: triglycerides; HDL-c: high-density lipoprotein cholesterol; LDL-c: low-density lipoprotein cholesterol; LH: luteinizing hormone; FSH: folliclestimulating hormone; PRL: prolactin; E2: estradiol; PROG: progesterone; TESTO: testosterone; DHEA: dehydroepiandrosterone.}

\section{Competing interests}

The authors declare that they have no competing interests.

\section{Authors' contributions}

XG and HY designed the research and revised the manuscript; QL and WW carried out the experiment and wrote the paper; $\mathrm{MX}$ and $\mathrm{HB}$ collected samples and took charge of detection of serum RBP4; $\mathrm{HL}$ and XC participated in data analysis; all authors have read and approved the final version of the manuscript.

\section{Authors' information}

Qian Li and Weiyun Wu are the co first author.

\section{Acknowledgements}

We thank Prof. Pu Xia for critical reading and editing the manuscript and the colleagues in Zhongshan Hospital, Fudan University for assistance in recruiting patients to the study.

This study was supported by grants from the National Natural Science Foundation for young scholar,China (Grant 81200627 to Hongmei YAN), the Shanghai Municipal Health Project Grant (grant no. $2013 Z$ YJB0802 to X. Gao), and the Shanghai Health and Family Planning Commission Foundation (2013SY005 to X. Gao).

\section{Author details}

'Department of Endocrinology and Metabolism, Shanghai Zhongshan Hospital, Fudan University, Shanghai 200032, China. ${ }^{2}$ Department of Clinical Laboratory, Shanghai Zhongshan Hospital, Fudan University, Shanghai 200032, China.

Received: 31 December 2015 Accepted: 25 February 2016

Published online: 09 March 2016

\section{References}

1. Wongsiriroj N, Jiang H, Piantedosi R, Yang KJ, Kluwe J, Schwabe RF, et al. Genetic dissection of retinoid esterification and accumulation in the liver and adipose tissue. J Lipid Res. 2014;55(1):104-14.

2. Blaner WS. Retinol-binding protein: the serum transport protein for vitamin A. Endocr Rev. 1989;10(3):308-16.

3. Zabetian-Targhi F, Mahmoudi MJ, Rezaei N, Mahmoudi M. Retinol binding protein 4 in relation to diet, inflammation, immunity, and cardiovascular diseases. Adv Nutr. 2015;6(6):748-62.

4. Li TY, Rana JS, Manson JE, Willett WC, Stampfer MJ, Colditz GA, et al. Obesity as compared with physical activity in predicting risk of coronary heart disease in women. Circulation. 2006;113(4):499-506.

5. Wilson PW, D'Agostino RB, Sullivan L, Parise H, Kannel WB. Overweight and obesity as determinants of cardiovascular risk: the Framingham experience. Arch Intern Med. 2002;162(16):1867-72.

6. Graham TE, Yang Q, Bluher M, Hammarstedt A, Ciaraldi TP, Henry RR, et al. Retinol-binding protein 4 and insulin resistance in lean, obese, and diabetic subjects. N Engl J Med. 2006;354(24):2552-63.

7. Gavi S, Stuart LM, Kelly P, Melendez MM, Mynarcik DC, Gelato MC, et al. Retinol-binding protein 4 is associated with insulin resistance and body fat distribution in nonobese subjects without type 2 diabetes. J Clin Endocrinol Metab. 2007;92(5):1886-90.

8. Sun Q, Kiernan UA, Shi L, Phillips DA, Kahn BB, Hu FB, et al. Plasma retinolbinding protein 4 (RBP4) levels and risk of coronary heart disease: a prospective analysis among women in the nurses' health study. Circulation. 2013;127(19):1938-47.

9. Janke J, Engeli S, Boschmann M, Adams F, Bohnke J, Luft FC, et al. Retinolbinding protein 4 in human obesity. Diabetes. 2006;55(10):2805-10.

10. Santoro N, Perrone L, Cirillo G, Brienza C, Grandone A, Cresta N, et al. Variations of retinol binding protein 4 levels are not associated with changes in insulin resistance during puberty. J Endocrinol Invest. 2009; 32(5):411-4.

11. Jia J, Bai J, Liu Y, Yin J, Yang P, Yu S, et al. Association between retinolbinding protein 4 and polycystic ovary syndrome: a meta-analysis. Endocr J. 2014;61(10):995-1002.

12. An C, Wang H, Liu X, Li Y, Su Y, Gao X, et al. Serum retinol-binding protein 4 is elevated and positively associated with insulin resistance in postmenopausal women. Endocr J. 2009;56(8):987-96.

13. Cho YM, Youn BS, Lee H, Lee N, Min SS, Kwak SH, et al. Plasma retinolbinding protein- 4 concentrations are elevated in human subjects with impaired glucose tolerance and type 2 diabetes. Diabetes Care. 2006;29(11):2457-61.

14. Qi Q, Yu Z, Ye X, Zhao F, Huang P, Hu FB, et al. Elevated retinol-binding protein 4 levels are associated with metabolic syndrome in Chinese people. J Clin Endocrinol Metab. 2007:92(12):4827-34.

15. Gordon-Larsen P, Wang H, Popkin BM. Overweight dynamics in Chinese children and adults. Obes Rev. 2014;15 Suppl 1:37-48.

16. Wolf $\mathrm{G}$. Serum retinol-binding protein: a link between obesity, insulin resistance, and type 2 diabetes. Nutr Rev. 2007;65(5):251-6. 
17. Yang Q, Graham TE, Mody N, Preitner F, Peroni OD, Zabolotny JM, et al. Serum retinol binding protein 4 contributes to insulin resistance in obesity and type 2 diabetes. Nature. 2005;436(7049):356-62.

18. Aeberli I, Biebinger R, Lehmann R, L'Allemand D, Spinas GA, Zimmermann $M B$. Serum retinol-binding protein 4 concentration and its ratio to serum retinol are associated with obesity and metabolic syndrome components in children. J Clin Endocrinol Metab. 2007;92(11):4359-65.

19. Kowalska I, Straczkowski M, Adamska A, Nikolajuk A, Karczewska-Kupczewska $M$, Otziomek $E$, et al. Serum retinol binding protein 4 is related to insulin resistance and nonoxidative glucose metabolism in lean and obese women with normal glucose tolerance. J Clin Endocrinol Metab. 2008;93(7):2786-9.

20. Choi KM, Yannakoulia M, Park MS, Cho GJ, Kim JH, Lee SH, et al. Serum adipocyte fatty acid-binding protein, retinol-binding protein 4, and adiponectin concentrations in relation to the development of the metabolic syndrome in Korean boys: a 3-y prospective cohort study. Am J Clin Nutr. 2011;93(1):19-26.

21. Kanaka-Gantenbein C, Margeli A, Pervanidou P, Sakka S, Mastorakos G, Chrousos GP, et al. Retinol-binding protein 4 and lipocalin-2 in childhood and adolescent obesity: when children are not just "small adults". Clin Chem. 2008;54(7):1176-82.

22. Broch M, Vendrell J, Ricart W, Richart C, Fernandez-Real JM. Circulating retinol-binding protein-4, insulin sensitivity, insulin secretion, and insulin disposition index in obese and nonobese subjects. Diabetes Care. 2007:30(7):1802-6.

23. Lewis JG, Shand BI, Frampton CM, Elder PA, Scott RS. Plasma retinol-binding protein is not a marker of insulin resistance in overweight subjects: a three year longitudinal study. Clin Biochem. 2008:41(13):1034-8.

24. Lee DC, Lee JW, Im JA. Association of serum retinol binding protein 4 and insulin resistance in apparently healthy adolescents. Metabolism. 2007;56(3): 327-31

25. Balagopal P, Graham TE, Kahn BB, Altomare A, Funanage V, George D. Reduction of elevated serum retinol binding protein in obese children by lifestyle intervention: association with subclinical inflammation. J Clin Endocrinol Metab. 2007:92(5):1971-4.

26. Chan TF, Tsai YC, Chiu PR, Chen YL, Lee CH, Tsai EM: Serum retinol-binding protein 4 levels in nonobese women with polycystic ovary syndrome. Fertil Steril. 2010;93(3):869-73.

27. Tan BK, Chen J, Lehnert H, Kennedy R, Randeva HS. Raised serum, adipocyte, and adipose tissue retinol-binding protein 4 in overweight women with polycystic ovary syndrome: effects of gonadal and adrenal steroids. J Clin Endocrinol Metab. 2007;92(7):2764-72.

28. Yi KW, Shin JH, Seo HS, Lee JK, Oh MJ, Kim T, et al. Role of estrogen receptor-alpha and -beta in regulating leptin expression in 3T3-L1 adipocytes. Obesity (Silver Spring). 2008;16(11):2393-9.

29. Matsuda M, Masui F, Mori T. Neonatal estrogenization leads to increased expression of cellular retinol binding protein 2 in the mouse reproductive tract. Cell Tissue Res. 2004;316(1):131-9.

30. Combs TP, Berg AH, Rajala MW, Klebanov S, lyengar P, Jimenez-Chillaron JC, et al. Sexual differentiation, pregnancy, calorie restriction, and aging affect the adipocyte-specific secretory protein adiponectin. Diabetes. 2003;52(2):268-76.

31. Rosenbaum M, Pietrobelli A, Vasselli JR, Heymsfield SB, Leibel RL. Sexual dimorphism in circulating leptin concentrations is not accounted for by differences in adipose tissue distribution. Int J Obes Relat Metab Disord. 2001;25(9):1365-71.

32. Van Pelt RE, Gozansky WS, Hickner RC, Schwartz RS, Kohrt WM. Acute modulation of adipose tissue lipolysis by intravenous estrogens. Obesity (Silver Spring). 2006;14(12):2163-72.

33. Pedersen SB, Kristensen K, Hermann PA, Katzenellenbogen JA, Richelsen B. Estrogen controls lipolysis by up-regulating alpha2A-adrenergic receptors directly in human adipose tissue through the estrogen receptor alpha. Implications for the female fat distribution. J Clin Endocrinol Metab. 2004:89(4):1869-78.

34. Morselli E, Fuente-Martin E, Finan B, Kim M, Frank A, Garcia-Caceres C, et al. Hypothalamic PGC-1alpha protects against high-fat diet exposure by regulating ERalpha. Cell Rep. 2014;9(2):633-45.

35. Palmer BF, Clegg DJ. The sexual dimorphism of obesity. Mol Cell Endocrinol. 2015;402:113-9.

36. Chang X, Yan H, Bian H, Xia M, Zhang L, Gao J, et al. Serum retinol binding protein 4 is associated with visceral fat in human with nonalcoholic fatty liver disease without known diabetes: a cross-sectional study. Lipids Health Dis. 2015;14:28.
37. Kloting N, Graham TE, Berndt J, Kralisch S, Kovacs P, Wason CJ, et al. Serum retinol-binding protein is more highly expressed in visceral than in subcutaneous adipose tissue and is a marker of intra-abdominal fat mass. Cell Metab. 2007:6(1):79-87.

38. Lee JW, Im JA, Lee HR, Shim JY, Youn BS, Lee DC. Visceral adiposity is associated with serum retinol binding protein-4 levels in healthy women. Obesity (Silver Spring). 2007;15(9):2225-32

39. Jia W, Wu H, Bao Y, Wang C, Lu J, Zhu J, et al. Association of serum retinolbinding protein 4 and visceral adiposity in Chinese subjects with and without type 2 diabetes. J Clin Endocrinol Metab. 2007;92(8):3224-9.

40. Kim IK, Lee HJ, Kang JH, Song J. Relationship of serum retinol-binding protein 4 with weight status and lipid profile among Korean children and adults. Eur J Clin Nutr. 2011;65(2):226-33.

41. Goodman E, Graham TE, Dolan LM, Daniels SR, Goodman ER, Kahn BB. The relationship of retinol binding protein 4 to changes in insulin resistance and cardiometabolic risk in overweight black adolescents. J Pediatr. 2009;154(1): 67-73.

42. Staels B. Regulation of lipid and lipoprotein metabolism by retinoids. J Am Acad Dermatol. 2001:45(5):S158-67.

\section{Submit your next manuscript to BioMed Central and we will help you at every step:}

- We accept pre-submission inquiries

- Our selector tool helps you to find the most relevant journal

- We provide round the clock customer support

- Convenient online submission

- Thorough peer review

- Inclusion in PubMed and all major indexing services

- Maximum visibility for your research

Submit your manuscript at www.biomedcentral.com/submit
) Biomed Central 